\title{
Expenditure Flows Near Widowhood
}

\author{
Jessie X. Fan \\ Cathleen D. Zick \\ University of Utah
}

\begin{abstract}
Using data from the 1980-2001 Consumer Expenditure Surveys, we investigate how impending widowhood affects households' expenditure patterns. We find that total annual expenditures are $\$ 4,027$ higher for about-to-be-widowed households compared to otherwise comparable continuously married couples. Within subcategories, expenditures average $\$ 4,108$ higher for the miscellaneous subcategory which includes expenditures on funerals/burials. We conclude that differences in the needs-adjusted incomes of married and widowed households may be partly a function of pre-widowhood differences in their expenditure patterns that lead about-to-be-widowhood households to draw down on financial wealth.
\end{abstract}

KEY WORDS: budget allocation; Consumer Expenditure Survey; expenditure pattern; widowhood.

Widowhood is a life event that sparks economic changes within a household. Over the past twenty years, it has been well documented that widowed individuals typically have a lower level of needs-adjusted income than their married counterparts (Bound, Duncan, Laren, \& Oleinick, 1991; Holden, Burkhauser, \& Feaster, 1988; Hurd \& Wise, 1989; Weir \& Willis, 2000; Zick \& Smith, 1991). Explanations for this difference have generally centered on the loss of earnings and/or retirement income that accompanies a death (Holden, Burkhauser, \& Feaster, 1988; Holden \& Zick, 1998). More recently, studies have found evidence that the spending patterns of soon-to-be widowed households may also contribute to their economic decline. Evidence of elevated spending on health care and funeral/burial arrangements are hypothesized to reduce household wealth which in turn jeopardizes the surviving spouse's post-widowhood economic position (Fan \& Zick, 2004; McGarry \& Schoeni, 2002; Zick, Fan, \& Chang, 2004). Yet, it may be that households that spend more on health care and funeral/

Jessie X. Fan, University of Utah, 225 S 1400 E, AEB 228, Salt Lake City, UT $84112-$ 0080, USA; e-mail: fan@fcs.utah.edu.

Cathleen D. Zick, University of Utah, 225 S 1400 E, AEB 228, Salt Lake City, UT 84112-0080, USA; e-mail: zick@fcs.utah.edu. 
burial arrangements reduce their expenditures in other domains rather than taxing their financial wealth to meet these rising expenses.

In this paper, we examine the expenditure patterns of a group of about-to-be-widowed couples and compare them to the expenditures of an otherwise similar group of continuously married couples. Our analyses are focused on answering two questions. First, to what extent does impending widowhood affect overall household expenditures? Second, are increases in specific expenditure categories offset by decreases in other expenditure categories? Data for our empirical work are drawn from the 1980-2001 Consumer Expenditure (CE) Surveys.

\section{The Literature}

There is a long history dating back to Prais and Houthakker (1971) of investigating households' budget allocations using consumer demand theory. This literature stresses the roles that income, prices, and preferences play in household expenditure patterns. Recent work has looked in greater detail at the role that preferences, as approximated by sociodemographic variables, play in expenditure decisions. For example, one recent study has compared and contrasted the expenditure patterns of families receiving public assistance compared to families receiving no public assistance (Tan, 2000), while another has examined the expenditure patterns of single-parent households headed by women compared to single-parent households headed by men (Paulin \& Lee, 2002).

To date, no one has investigated how impending widowhood influences household expenditures; nevertheless, investigations that focus on the role of age or retirement status offer some insights for this study because of their association with impending widowhood. The risk of mortality increases with age and thus we would expect that observed differences in age-related expenditure patterns may be partially explained by this rising risk of mortality-which is typically not controlled for directly in the analyses that focus on the role of age. The authors of these studies generally conclude that there are significant differences in expenditure patterns by age group (i.e., reference person age 65-74 versus 75 and older) and that other socio-demographic preference shifters exert considerable influence on expenditures among both the young-old and the old-old (Abdel-Ghany \& Sharpe, 1997; Paulin, 2000; Rubin \& Nieswiadomy, 1997). Significant preference shifters typically include education, race/ethnicity, housing tenure, region of residence, and family type (i.e., married couple, unmarried female/male head). Some of these variables are also asso- 
ciated with the risk of mortality (e.g., race/ethnicity, education). Thus, it is important that we control for these preference-shifting variables in our analyses so that we can obtain unbiased estimates of the effect of impending widowhood.

One study has examined how retirement affects household expenditure patterns. Paulin and Duly (2002) use data from the 1998 and 1999 CE Survey to examine how the expenditure patterns of households that have no labor income and where the reference person is age 65-74 compare to those of households where there is reported labor income and the reference person is between the ages of 55 and 64 . Among married couples, Paulin and Duly (2002) observe that the effect of being retired and its associated change in household income contribute to significant declines in expenditures on food away from home and apparel and services. If retirement is associated with declining health status (as well as with changing income and opportunity costs of time), one might also posit that impending widowhood would be associated with decreased expenditures in these categories.

A key methodological issue that cuts across virtually all applications of the economic model of household expenditures is the measurement of income. Theory suggests that households' consumption choices are influenced by permanent or life-cycle income (Bryant, 1990; Deaton \& Muellbauer, 1980). Yet, it is difficult to obtain a permanent income measure when working with cross-sectional data. Current income is an imprecise approximation of permanent income because it contains a random, transitory component. A strategy adopted by many researchers has been to use total household expenditures rather than current income as a proxy for permanent income (Paulin, 2000; Paulin $\&$ Lee, 2002; Rubin \& Nieswiadomy, 1997). The argument being that total household expenditures is a better approximation of permanent income than is current income.

Other researchers who are interested in estimating income shares (typically for public policy reasons) have examined consumer expenditures using current income (Fan \& Zick, 2004). The use of current income allows one to assess whether or not current expenditures are exhausting current income and thus depleting wealth and we thus follow this latter strategy.

The description of the methods that follows draws on the insights gained from earlier expenditure research to investigate how impending widowhood affects consumer expenditure patterns. Our model and estimation give particular attention to the role that impending widowhood plays controlling for current income, prices, and other traditional preference shifters. 


\section{Methods}

We draw on both the neoclassical economics framework to inform the specification of our multivariate analyses. Proponents of the neoclassical economics framework argue that household expenditures are influenced by income, prices, and preferences. Mathematically,

$$
\begin{gathered}
M=m(Y, D, G) \\
E_{i}=e_{i}(Y, P, D, G) ; \quad i=1,2, \ldots n ; \\
W_{i}=w_{i}(Y, P, D, G) ; \quad i=1,2, \ldots n ;
\end{gathered}
$$

where, $M$ is total expenditure, $Y$ is after-tax income, and $W_{i}$ is the budget share for expenditure category $i . E_{i}$ is the dollar amount for expenditure category $i . P$ is a price vector for commodities and services. $D$ is a vector of demographic variables representing preferences, and $G$ is widowhood status.

Our goal in the multivariate analysis is to identify how impending widowhood affects the household's total expenditures and its expenditures in specific subcategories controlling for income, prices, and preferences. We include preference measures that have been affirmed in past consumer expenditure research as being significant predictors of household expenditures (see Abdel-Ghany \& Sharpe, 1997; Paulin, 2000; Rubin \& Nieswiadomy, 1997). Specifically, our analyses will control for age, employment status, race/ethnicity, education, residential location, family size, presence or absence of private medical insurance, housing tenure, and interview year.

The data for our study come from the interview portion of the 19802001 Consumer Expenditure Surveys (U.S. Bureau of Labor Statistics \& Department of Labor, 1980-2001). Because we are interested in looking at total expenditure changes and budget tradeoffs for the about-to-be widowed households, $\mathrm{CE}$ is the only data set available in the U.S. that provides such information. For more specific expenditure categories, such as health care, other data sets, such as Medical Expenditure Panel Survey (MEPS) and Health and Retirement Survey/Assets and Health Dynamics (HRS/AHEAD) may be more suitable. However, for total expenditure and budget allocation studies, the $\mathrm{CE}$ is the best data set available. It is the most comprehensive source of detailed information on family expenditures, income, and other socioeconomic and demographic characteristics of the U.S. non-institutionalized civilian population. The CE Survey is conducted quarterly with rotating panels of approximately 5,000-7,000 families, who are 
interviewed for five consecutive quarters. One-fifth of the sample is new each quarter. The unit of analysis in the CE Survey is the consumer unit (CU), which is defined as all members of a household related by blood, marriage, adoption or other legal arrangements; or as someone living alone or sharing quarters with others but financially independent; or as two or more persons who pool income and make joint expenditures (U.S. Bureau of Labor Statistics \& Department of Labor, 1980-2001).

Widowhood is an extremely rare event at very young ages. Thus, the sample used in this study is restricted to respondents age 40 or above at the beginning of their participation in the survey. Two groups of respondents age 40 and above are included in the sample: (1) those who report they are married to the same person in all interviews and information on both spouses is available in the data (i.e., the continuously married), and (2) those who report subsequent to the first interview that their marital status has changed from married to widowed with spousal information before the widowhood event available in the data (i.e., the about-to-be-widowed). In addition, because the estimates in expenditure studies involving health care expenditures are very sensitive to outliers, CUs with real out-of-pocket medical expenditures outside six standard deviations from the sample mean are excluded (about $1 \%$ of the sample). The final sample size for the continuously married group is 27,946 . The sample size for the about-to-be-widowed group is 146. A separate sample of married CUs with both spouses 40 or older at the first interview who did not participate in all four interviews is also selected for the purpose of estimating sample selection biases due to non-participation in subsequent interviews. The size of this sample is 5,369.

For the about-to-be-widowed group, we designate the spouse who died during the panel as the reference spouse. For the continuously married sample, we make a random assignment using the gender distribution of the about-to-be-widowed sample to create a pseudo reference spouse. This insures that the continuously married households have the same gender distribution of reference spouses as the about-to-be-widowed households. Thus, in households where the husband is designated as the reference person, it is his education, race, age, and employment status that are being measured. In households where the wife is designated as the reference person, it is her education, race, age, and employment status that are being measured.

Given the small sample size for the about-to-be-widowed group and given our focus on expenditures, we elect to keep both complete income 
reporters and incomplete income reporters in our sample although we recognize the income data quality is affected by this decision (Garner \& Blanciforti, 1994). Our method of addressing this issue of income measurement is presented later in the paper when we discuss variable measurements in the multivariate analysis.

We investigate household annual expenditure on seven categories: (1) food at home, (2) primary housing and related services, including shelter, fuel and utilities, household operation, household furnishings, and equipment, (3) apparel and personal care, (4) health care, including prescription drugs, health insurance, medical services, and medical supply, (5) transportation, (6) recreation, including entertainment, food away from home, vacation lodging, and reading, and (7) miscellaneous, including education, alcohol beverages, tobacco products, cash contributions, personal insurance, funeral and burial, and other services. This categorization of expenditures is similar to that used by Paulin (1995), with the exception of personal care which he combines with health related expenditures to create a health and personal care category. The expenditure variables we examine are measured as the sum of four quarterly expenditures reported in the year. The measurement of the price vector $P$ includes an inflation adjustment and additional variables controlling for cross-sectional differences. The Consumer Price Index (CPI) is used to adjust all income and expenditure figures to 2001 constant dollars. Region of residence (urban south, rural, and others) is used to capture regional price differences. In addition, presence/absence of health insurance is used to capture cross-sectional differences in out-of-pocket health care price as those with insurance face lower prices than those without due to third party payments.

Descriptive statistics on the sample characteristics and their expenditure patterns are first computed for both groups. Next, we control for income, prices, and basic life-course characteristics to see if the about-to-be-widowed group spends more compared to the continuously-married group, ceteris paribus. In the multivariate analyses, income is measured as the household's reported after-tax annual income at the last interview because this income measure covers the same period as the expenditure measures used in this study. Imputations were done for those CUs that were incomplete income reporters. We first estimated a regression equation with the dependent variable being the log of after-tax income for those households who were complete income reporters. This dependent variable is regressed on age, age squared, gender, race, education, occupation, work status, region, widowhood status, and year. The regression equation was then 
used to predict after-tax income for the incomplete income reporters. A random error component generated from a normal distribution with a mean of zero and an estimated standard deviation of the residual term from the regression equation was added to the predicted value. In addition, we control for income reporting status (i.e., complete versus incomplete reporter) in all of our multivariate analyses by adding a dummy variable indicating incomplete income reporting status.

Family size for the about-to-be-widowed group is adjusted by assuming that the reference spouse died at the midpoint between the two interviews since we do not have information on the exact date of death. In addition to this adjustment, we use the average family size for the four quarters as our measurement. Measurements of all other variables are self-explanatory.

For the total expenditure equation (i.e., Equation 1), generalized least squares estimation is used. But, for the seven expenditure categories, the error terms of these expenditure categories are likely to be correlated. As a consequence, a Seemingly Unrelated Regression (SUR) estimation method is used (Greene, 1993) and the equations for the seven expenditure categories are simultaneously fitted. Two sets of equations are estimated, with expenditure amounts as the dependent variables for the first set (i.e., following the format of Equation 2) and budget shares as the dependent variables in the second set (i.e., following the format of Equation 3). We also correct for sample selection bias due to the fact that not all households participate in all four quarterly interviews. In addition, we explore the possibility of estimating models separately for the about-to-be-widowed and the continuously married groups. Initial tests (available from the authors upon request) show that the coefficients on the independent variables do not vary significantly across the two groups. Therefore, in our final models, we pool the data and include only a group dummy. Finally, we test for gender differences between about-to-be widowers and aboutto-be widows. While we find that about-to-be widowers spend significantly more on health care than about-to-be widows, the small sample size of the about-to-be widowers $(N=30)$ prevents us from investigating this issue further with confidence.

\section{Results}

In Table 1 the weighted demographic profile of the sample is presented. The about-to-be-widowed group is older than the continuouslymarried group because of the positive correlation between the risk of 
Journal of Family and Economic Issues

TABLE 1

Weighted Demographic Characteristics by Group

\begin{tabular}{lcc}
\hline Variable & $\begin{array}{c}\text { About-to-be } \\
\text { widowed }(n=146)\end{array}$ & $\begin{array}{c}\text { Continuously } \\
\text { married }(n=27,946)\end{array}$ \\
\hline $\begin{array}{l}\text { Total after-tax income in } \$ 10,000 \\
\text { (Standard deviation) }\end{array}$ & $2.18(1.61)$ & $5.58(4.82)$ \\
Incomplete income reporter $(\%)$ & 11.52 & 16.31 \\
Age (Standard deviation) & $67.70(11.27)$ & $57.71(11.24)$ \\
Employed (\%) & 29.86 & 64.56 \\
African American (\%) & 13.16 & 5.90 \\
Hispanic American (\%) & 2.00 & 4.50 \\
More than high school education (\%) & 21.83 & 29.31 \\
Residing in urban South (\%) & 23.02 & 24.72 \\
Residing in rural areas (\%) & 10.37 & 15.88 \\
Family size (Standard deviation) & $2.25(1.10)$ & $2.92(1.27)$ \\
Having private medical insurance (\%) & 81.64 & 82.76 \\
Homeowner w/ mortgage (\%) & 28.57 & 48.28 \\
Homeowner w/o mortgage (\%) & 55.76 & 42.30 \\
Year (1980 = 1, 2001 = 21) (Standard deviation) & $10.64(6.05)$ & $12.03(6.12)$ \\
\hline
\end{tabular}

mortality and age. On average, compared to their continuously married counterparts, the about-to-be-widowed group has a lower average income, a result consistent with previous work that has found an inverse relationship between income and the risk of mortality (Daly, Duncan, Kaplan, \& Lynch, 1998; McDonough, Duncan, Williams, \& House, 1997). In addition, a higher proportion of the about-to-bewidowed group is minority, compared to the continuously-married group, and the reference spouse in the about-to-be-widowed group is less likely to be employed than the reference spouse in the continuously-married group. The lower levels of economic well-being and labor force participation among the about-to-be-widowed may be the result of one or both spouses cutting back on their labor supply because of the to-be-deceased spouse's declining health. The difference in the racial composition may reflect the relatively higher mortality risk faced by black individuals (Arias, 2002).

The about-to-be-widowed households are also more likely to be either renters $(15.67 \%)$ or homeowners without a mortgage $(55.76 \%)$, compared to continuously-married households (9.42 and $42.30 \%$, respectively). This difference is likely a result of differences in life cycle stage. A lower percentage of the about-to-be-widowed households live in rural areas than the continuously married households, possibly because of the higher percentage of African American households in the about-to-be-widowed sample and their greater tendency to live in 
urban areas than European Americans. Regardless of the reasons for these differences, they do suggest that controlling for these sociodemographic preference shifters may be particularly important in the multivariate analyses if we are to get a clear assessment of the ceteris paribus impact of impending widowhood on household expenditures.

Table 2 presents means and distributional information for the seven expenditure categories as well as the totals. At the descriptive level, total out-of-pocket expenditures are lower for the about-to-be-widowed group compared to the continuously married group. On average, the continuously married households spend $\$ 44,474$ per year, while the about-to-be-widowed households spend $\$ 31,747$ per year. At the sample mean level, the only category where the about-to-be-widowed group spends more is on health care, at $\$ 3,023$ on average versus the $\$ 2,784$ for the continuously married group. This difference does not reach conventional levels of statistical significance, however. The other category that is not significantly different between the two groups is the miscellaneous category. For the remaining five categories-food at home, housing, apparel and personal care, transportation, and recreation - the continuously married households spend significantly more than the about-to-be-widowed households.

In terms of budget shares, the about-to-be-widowed group allocates significantly more of their money to housing, health care, and miscellaneous, but less to apparel, transportation, and recreation. The budget share for food at home is not significantly different between the two groups at the descriptive level. The budget shares reported in Table 2 for the continuously married group are similar to those reported in other studies that have focused on expenditure patterns among older Americans (Paulin \& Duly, 2002; Rubin \& Nieswiadomy, 1997).

The next step is to estimate descriptive, multivariate regressions for total expenditures and the seven expenditure categories to see if the differences observed at the bivariate level continue to exist after controlling for income and the standard set of socio-demographic preference shifters. The independent variables in these descriptive regressions include the socio-economic characteristics identified in Table 1 . For the seven expenditure equations, the adjusted $R^{2}$ ranges from 0.12 for health care to 0.32 for food at home. For the six budget share equations (apparel and personal care budget share is not directly estimated to insure that the adding-up constraint is met), the adjusted $R^{2}$ ranges from 0.04 for transportation to 0.31 for health care. Because of space limitations, we elect not to present the results of the 
Journal of Family and Economic Issues

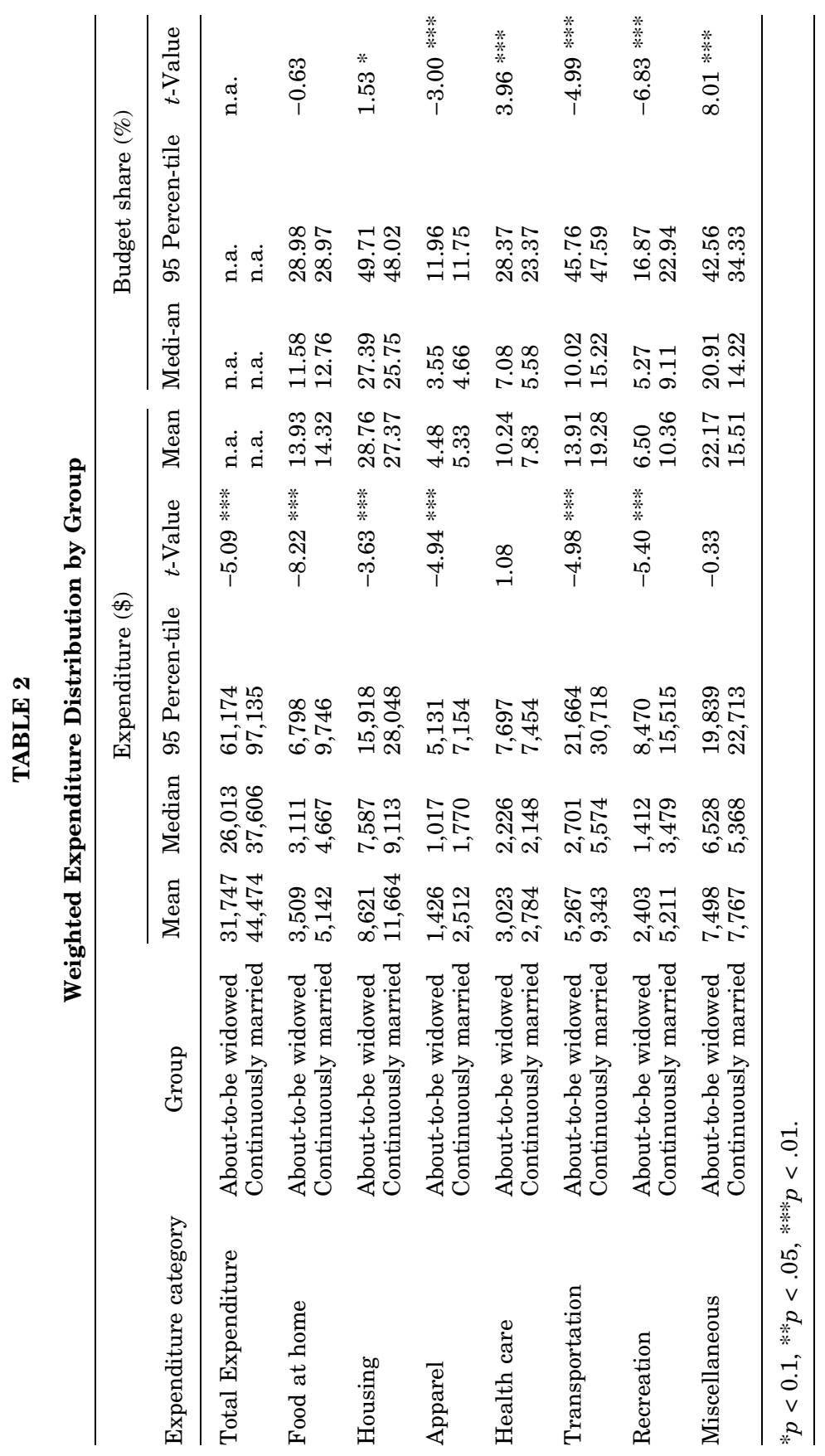


multivariate regressions for the seven expenditure categories. These results are available from the authors upon request.

Focusing first on the differences between the about-to-be widowed group and the continuously married group, Table 3 presents the mean predicted expenditures for each of the seven categories based on the regression results, holding everything else equal. The predictions are conducted using the 146 about-to-be-widowed households. First, expenditures and budget shares are predicted using the reference person's characteristics and widowhood status. The means, which are the same as the descriptive sample means, are reported in Table 3 next to the heading "about-to-be-widowed." Second, we change these households' widowhood status to being continuously married while retaining all other characteristics. Then we predict their expenditures and budget shares using our regression results. The means for these predictions are presented also in Table 3 next to the "continuously

TABLE 3

Simulated Expenditures by Group Holding Everything Else Equal

\begin{tabular}{|c|c|c|c|c|c|}
\hline \multirow[b]{2}{*}{ Expenditure category } & \multirow[b]{2}{*}{ Group } & \multicolumn{2}{|c|}{ Expenditure (\$) } & \multicolumn{2}{|c|}{ Budget share (\%) } \\
\hline & & $\begin{array}{l}\text { Predicted } \\
\text { mean }\end{array}$ & $t$-value & $\begin{array}{l}\text { Predicted } \\
\text { mean }\end{array}$ & $t$-value \\
\hline Total Expenditure & $\begin{array}{l}\text { About-to-be widowed } \\
\text { Continuously married }\end{array}$ & $\begin{array}{l}31,747 \\
27,720\end{array}$ & $1.97 * *$ & $\begin{array}{l}\text { n.a. } \\
\text { n.a. }\end{array}$ & n.a. \\
\hline Food at home & $\begin{array}{l}\text { About-to-be widowed } \\
\text { Continuously married }\end{array}$ & $\begin{array}{l}3,509 \\
4,075\end{array}$ & $-3.42 * * *$ & $\begin{array}{l}13.93 \\
17.16\end{array}$ & $-6.04 * * *$ \\
\hline Housing & $\begin{array}{l}\text { About-to-be widowed } \\
\text { Continuously married }\end{array}$ & $\begin{array}{l}8,621 \\
7,808\end{array}$ & 1.10 & $\begin{array}{l}28.76 \\
29.82\end{array}$ & -1.28 \\
\hline Apparel & $\begin{array}{l}\text { About-to-be widowed } \\
\text { Continuously married }\end{array}$ & $\begin{array}{l}1,426 \\
1,475\end{array}$ & -0.48 & $\begin{array}{l}4.48 \\
4.69\end{array}$ & n.a. \\
\hline Health care & $\begin{array}{l}\text { About-to-be widowed } \\
\text { Continuously married }\end{array}$ & $\begin{array}{l}3,023 \\
2,920\end{array}$ & -0.12 & $\begin{array}{l}10.24 \\
11.49\end{array}$ & $-2.46 * *$ \\
\hline Transportation & $\begin{array}{l}\text { About-to-be widowed } \\
\text { Continuously married }\end{array}$ & $\begin{array}{l}5,267 \\
5,363\end{array}$ & 0.01 & $\begin{array}{l}13.91 \\
16.81\end{array}$ & $-2.74 * * *$ \\
\hline Recreation & $\begin{array}{l}\text { About-to-be widowed } \\
\text { Continuously married }\end{array}$ & $\begin{array}{l}2,409 \\
2,689\end{array}$ & -0.61 & $\begin{array}{l}6.49 \\
8.56\end{array}$ & $-3.89 * * *$ \\
\hline Miscellaneous & $\begin{array}{l}\text { About-to-be widowed } \\
\text { Continuously married }\end{array}$ & $\begin{array}{l}7,498 \\
3,390\end{array}$ & $5.47 * * *$ & $\begin{array}{l}22.17 \\
11.46\end{array}$ & $14.33 * * *$ \\
\hline
\end{tabular}

Note. The simulation was conducted using the 146 about-to-be widowed households. The numbers are to be interpreted as follows: The average total expenditure for these 146 about-to-be widowed households was $\$ 31,747$. If these households were continuously married, then their average total expenditure would have been only $\$ 27,720$, which is equivalent to a reduction of $\$ 4,027$. This dierence is statistically significant at the $95 \%$ level.

$* p<0.1, * * p<.05, * * * p<.01$. 
married" heading. $T$-test results from the regressions are also reported in the table.

Table 3 reveals that for the year in question, the about-to-be-widowed households spend significantly more money compared to what they would have spent if no death had occurred. The average annual predicted total expenditures are $\$ 31,747$ for the about-to-be-widowed households and $\$ 27,720$ for the otherwise identical continuously married households-a difference of about 15\%. This difference is statistically significant at the $95 \%$ level. Among the seven expenditure categories, two stand out as being significantly different between these two groups: food at home, and miscellaneous, which includes funeral and burial expenditures. Everything else equal, compared to the continuously married households, the about-be-be widowed households spend $\$ 566$ less money on food at home ( $\$ 3,509$ versus $\$ 4,075)$, but $\$ 4,108$ more on miscellaneous ( $\$ 7,498$ versus $\$ 3,390$ ).

The predicted numbers on budget shares reveal that the typical household in the about-to-be-widowed group allocates more of its budget to miscellaneous, but less on food at home, health care, transportation, and recreation, compared to an otherwise identical continuously married household. Reinforcing the result on the difference in the miscellaneous expenditure category, about-to-be-widowed households allocate an average of $22.17 \%$ of their annual budget to the miscellaneous category, compared to the $11.46 \%$ they would otherwise allocate if the widowhood event did not occur. Because of adding-up constraints, they have to allocate less of their budget to other expenditure categories. The predictions show that those categories where less money is allocated include food at home (3.23\% less), health care ( $1.25 \%$ less), transportation (2.90\% less), and recreation $(2.07 \%$ less).

We report estimates from multivariate regressions for total out-ofpocket expenditures in Table 4 . The adjusted $R^{2}$ for the total expenditure regression is 0.33 . In addition to the widowhood dummy, other variables that affect total expenditures include income, income reporting status, age, family size, education, region of residence, health insurance, housing tenure, and year of interview. As expected, households with higher income spend more than those with lower income. Those who did not report their complete income and therefore had their income imputed spend about $\$ 3,839$ less compared to their complete-income-reporting counterparts. Older individuals spend less out-of-pocket than do younger individuals. A one year increase in the age of the reference spouse is associated with a decline in spending of $\$ 288$. Households where the reference spouse was employed, had more than a high school education, had a larger family, and had private 
Jessie X. Fan and Cathleen D. Zick

TABLE 4

Results of Regression on Total Expenditure

\begin{tabular}{lrr}
\hline Independent variable & Parameter estimate & $t$-value \\
\hline Intercept & -29784 & $-10.00 * * *$ \\
Log of total after-tax income in $\$ 10,000$ & 9213.33 & $44.73 * * *$ \\
Incomplete income reporter & -3839.33 & $-9.33 * * *$ \\
Age & -288.10 & $-13.33 * * *$ \\
Employed & 3293.52 & $8.30 * * *$ \\
African American & -8748.97 & $-13.33 * * *$ \\
Hispanic American & -7211.67 & $-9.57 * * *$ \\
More than high school education & 7413.82 & $20.53 * * *$ \\
Residing in urban South & -1121.91 & $-3.08 * * *$ \\
Residing in rural areas & -5187.02 & $-12.40 * * *$ \\
Family size & 2209.38 & $16.35 * * *$ \\
Having private medical insurance & 3988.66 & $9.42 * * *$ \\
Homeowner w/ mortgage & 618.15 & 0.94 \\
Homeowner w/o mortgage & -7645.14 & $-11.41 * * *$ \\
Year & -145.38 & $-5.23 * * *$ \\
Correction for sample selection bias & -49699 & $-28.59 * * *$ \\
for reporting in all four quarters & & \\
About-to-be widowed & 4027.25 & $1.97 * *$ \\
Adjusted $R^{2}$ & 0.33 & \\
\hline
\end{tabular}

$* p<0.1, * * p<.05, * * * p<.01$.

health insurance spend more than those where the reference person was not employed, had less than a high school education, had a smaller family, and did not have private health insurance. In addition, African American households and Hispanic American households spend less than European American households. The difference is about $\$ 8,749$ less for African Americans and \$7,212 less for Hispanic Americans, other things equal. Households residing in the urban South and in rural areas, and households who are either renters or homeowners with a mortgage spend more. Finally, the coefficients on the year variable suggest that from 1980 to 2001, total expenditures decreased in real terms over this 22-year period by about $\$ 145$ per year. While it is possible that real expenditures decreased for those 40 and older over this period of time, this finding is more likely a result of the upward bias of the Consumer Price Index, which has been the subject of some discussion since the publication of the Boskin Commission Report (1996).

To keep the results parsimonious, we do not present the tables for the regression results on all seven expenditure categories (available from the authors upon request). Instead, we will simply highlight key findings. First, we found that the higher the after-tax income of the 
household, the more a household spends on all seven categories. However, the budget shares for food at home, housing, and health care decrease, while the budget shares for apparel, transportation, recreation, and miscellaneous increase. This result is consistent with previous findings (Paulin, 1995).

Second, consistent with Paulin (1995), we find that the older the reference spouse is, the less the household spends on food at home, housing, apparel, transportation, recreation, and miscellaneous, and the more the household spends on health care. In terms of budget shares, the older the reference spouse is, the more the household allocates its budget to food at home, housing, health care, but the less it allocates to transportation, recreation and miscellaneous.

Third, African American and Hispanic American families spend less on all seven expenditure categories, compared to European American families. However, higher budget shares are devoted to food at home, housing, and apparel, while less is devoted to health care and recreation. In the miscellaneous expenditure category, African American families allocate a higher percentage of their budgets than do European Americans, while Hispanic Americans allocate a lower percent of their budgets. No ethnic difference is found in budget shares allocated to transportation. These findings are consistent with previous studies (Fan \& Lewis, 1999; Fan \& Zuiker, 1998).

Fourth, households where the reference spouse has more than a high school education spend more on all seven expenditure categories than those where the reference spouse has a high school education or less. From a budget share perspective, more is allocated to apparel, recreation, and miscellaneous by those with more than a high school education, while less is allocated to food at home, health care, and transportation. There is no difference in budget shares allocated to housing between these two groups. Except for the health care category, these results are consistent with the work of Paulin (1995). Paulin found no statistical significant difference in the budget share for health and personal care between households with more than a high school education and households with a high school education. The difference may be a function of different definitions of the expenditure category; while Paulin (1995) combined personal care with health care, we do not.

Finally, over the years from 1980 to 2001, household expenditures on and budget shares for housing have increased, while expenditures on and budget shares for food, apparel, and miscellaneous have decreased. While expenditures for health care and recreation did not 
significantly increase over time for our sample, the budget shares for both categories increased.

\section{Discussion and Conclusions}

Our analyses reveal that about-to-be-widowed households differ from otherwise similar continuously married households in both their overall expenditures and in what they spend in various categories. Overall expenditures are, on average, $\$ 4,027$ higher in the about-tobe-widowed households, ceteris paribus. Within expenditure categories, the about-to-be-widowed households spend significantly more on miscellaneous ( $\$ 4,108$ on average) and significantly less on food at home ( $\$ 566$ on average); although the decrease in food at home does not come close to compensating for the increase in miscellaneous expenditures.

Recall that the miscellaneous category includes all expenditures related to education, alcoholic beverages, tobacco products, cash contributions, personal insurance, funerals and burials, and other services. Since the time period covered in our about-to-be-widowed sample includes the quarter in which the spouse died, it is probable that it is funeral/burial expenditures that contribute to the elevated spending in the miscellaneous category. This difference is consistent with earlier work by Fan and Zick (2004) where they examined funeral/burial expenditures in detail. They concluded that households where a spouse died averaged about $\$ 3,389$ more on funeral and burial services during the two quarters observed than otherwise similar households. Our estimates are lower, however, than the estimates of funeral prices obtained through the National Funeral Directors Association (NFDA) annual survey. In their 2001 survey, NFDA found that the average funeral price (excluding cemetery charges) was $\$ 6,130$ (National Funeral Directors Association, 2001). Similarly, the American Association of Retired Persons (AARP) (2002) notes that funeral and burial expenditures, when summed together, often exceed $\$ 10,000$. Our estimates may be lower than these because the $\mathrm{CE}$ Survey may not capture all of the funeral/burial expenses if they are spread out over an extended period of time. The fact that our annual estimate of a $\$ 4,108$ group difference for the miscellaneous category in this paper is higher than the six-month estimate of $\$ 3,389$ group difference for funeral and burial category in Fan and Zick (2004) supports this notion. 
If about-to-be-widowed households are spending significantly more on the miscellaneous category, are they compensating by spending less on other major expenditure categories? In our analyses, we find evidence of a modest reduction in expenditures on food at home, the average reduction being $\$ 566$. But, this reduction does not come close to compensating for the average $\$ 4,108$ increase in the miscellaneous category.

Our budget share analysis reaffirms the tradeoffs households may be making between food at home and miscellaneous expenditures and it also suggests that households may reduce expenditures on virtually all other categories, with the reduction of budget shares to transportation, recreation and health care being statistically significant. The result of the budget share analysis is consistent with the expenditure amount analysis. If the expenditure amount in a particular category for the about-to-be widowed group is either less than or no different from that of the continuously married group, then the substantial increase in the miscellaneous category would lead to a reduction of the budget share allocated to that particular category due to the addingup constraint. This is the case for expenditure categories of food at home, health care, transportation, and recreation.

Past studies have found that about-to-be widowed households spend more on health care than otherwise similar continuously married households (Fan \& Zick, 2004; McGarry \& Schoeni, 2002; Zick, et al., 2004). We did not find that in this study. Differences in sample, data collection method, age restrictions, and control of health status for the comparison group may contribute to our null finding. The CE Survey uses a net outlay method of measuring health care expenditures, while the MEPS uses an event method, and the HRS/AHEAD uses a recall method. To the extent that health care bills may come months after a death (and after the end of the one-year interviewing time frame), the CE Survey may understate overall health care expenditures related to an impending death. In addition, we restrict our analyses to couples age 40 and older while McGarry \& Schoeni (2002) used a sample of people age 70 and older. Finally, when comparing the health care expenditures of the two groups, Zick et al. (2004) found that it was important to control for the health status of the reference person in the continuously married group. Unfortunately, health status information is not available in the CE Survey.

Overall, our analysis suggests that about-to-be-widowed households make some modest downward adjustments in their expenditures on food at home in order to meet the costs of funeral/burial expenses but these reductions do not fully compensate for the increase in the mis- 
cellaneous expenditure category. In our sample of about-to-be-widowed households, the annual mean after-tax income is $\$ 21,800$ and the annual mean total expenditures is $\$ 31,747$. To meet the expenditures that are in excess of current income, households likely draw down on their financial assets. Using data from the Survey of Consumer Finance, Montalto (2001) estimates that the median net financial worth of households where the head is age 65 or older is $\$ 34,550$ (measured in 1998 dollars). Zick and Holden (2000) find that the median financial assets of a sample of about-to-be-widowed households in the Survey of Income and Program Participation is even more modest at $\$ 13,597$ (measured in 1996 dollars). Thus, even if expenditures exceed income by only a moderate amount, it could lead to a sizable percentage reduction in financial assets and contribute to a decline in post-widowhood economic well-being.

Our work supports the speculation that pre-widowhood differences in household expenditures patterns may be contributing to the observed declines in post-widowhood economic well-being for this group. Households where a spouse is about to die spend much more on miscellaneous goods and services (particularly funerals/burials) and they spend only moderately less on food at home than do otherwise similar households where no death is about to occur.

Caution must be used in interpreting our research because our sample of about-to-be widowed households is quite small. Nevertheless, we believe this analysis provides new, suggestive information on overall expenditure flows near widowhood. This research coupled with earlier work on income flows around widowhood helps create a more complete picture of why widowed households face greater risks of experiencing economic distress. Specifically, it would appear that widowed individuals' lower levels of economic well-being are likely a function of both the loss of earnings and/or retirement income that accompanies the death and expenditures that often exceed available income near the time of the death.

\section{Acknowledgments}

The research reported in this paper was supported by the National Institute on Aging Grant 1 R03 AG18902-01. We are grateful to Kuo-Liang Chang for his excellent research support. 


\section{Journal of Family and Economic Issues}

\section{References}

Abdel-Ghany, M., \& Sharpe, D. L. (1997). Consumption patterns among the young-old and old-old. Journal of Consumer Affairs, 31(1), 90-112.

American Association of Retired Persons. (2002). Funeral arrangements and memorial services. Retrieved May 24, 2005, from the American Association of Retired Persons Web site: http://www.aarp.org/griefandloss/articles/73_a.html.

Arias, E., (2002). United States life tables 2000. National Vital Statistics Reports 51(3). Retrieved May 24, 2005, from Center for Disease Control Web site: http:// www.cdc.gov/nchs/data/nvsr/nvsr51/nvsr51_03.pdf .

Boskin Commission. (1996). Toward a more accurate measure of the cost of living: Final report to the Senate Finance Committee from the Advisory Commission to Study the Consumer Price Index. Retrieved May 24, 2005, from the Social Security Administration Web site: http://www.ssa.gov/history/reports/boskinrpt.html.

Bound, J., Duncan, G. J., Laren, D. S., \& Oleinick, L. (1991). Poverty dynamics in widowhood. Journal of Gerontology: Social Sciences, 46, S115-S124.

Bryant, W. K. (1990). The economic organization of the household. New York: Cambridge University Press.

Daly, M. C., Duncan, G. J., Kaplan, G. A., \& Lynch, J. W. (1998). Macro-to-micro links in the relation between income inequality and mortality. Milbank Quarterly, 76, 315339.

Deaton, A., \& Muellbauer, J. (1980). Economics and consumer behavior. New York: Cambridge University Press.

Fan, J. X., \& Lewis, J. K. (1999). Budget allocation patterns of African Americans. Journal of Consumer Affairs, 33(1), 134-164.

Fan, J. X., \& Zick, C. D. (2004). An examination of the economic burden imposed by health care, funeral, and burial expenditures at the end of life. Journal of Consumer Affairs, 38(1), 35-55.

Fan, J. X., \& Zuiker, V. S. (1998). A comparison of household budget allocation patterns between Hispanic Americans and non-Hispanic White Americans. Journal of Family and Economic Issues, 19(2), 151-174.

Garner, T. I., \& Blanciforti, L. A. (1994). Household income reporting: An analysis of U.S. Consumer Expenditure Data. Journal of Official Statistics, 10(1), 69-71.

Greene, W. H. (1993). Econometric analysis. 2nd edition, New York: Macmillian Publishing.

Holden, K. C., Burkhauser, R. V., \& Feaster, D. J. (1988). The timing of falls into poverty after retirement and widowhood. Demography, 25, 405-414.

Holden, K.C., \& Zick, C. D. (1998). Insuring against the consequences of widowhood in a reformed Social Security System. In R. D. Arnold, M. J. Graetz, \& A. H. Munnell (Ed.), Framing the Social Security debate: Values, politics and economics (pp. 157181). Washington, DC: National Academy of Social Insurance.

Hurd, M. D., \& Wise, D. A. (1989). The wealth and poverty of widows: Assets before and after the husband's death. In D. A. Wise (Ed.), The economics of aging (pp. 177200). Chicago: University of Chicago Press.

McDonough, P., Duncan, G. J., Williams, D., \& House, J. (1997). Income dynamics and adult mortality in the United States, 1972 through 1989. American Journal of Public Health, 87, 1476-1483.

McGarry, K., \& Schoeni, R. F. (2002, May). Widow poverty and out-of-pocket medical expenditures at the end of life. Atlanta, GA: Paper presented at the Population Association of America's Annual Conference.

Montalto, C. P. (2001). Wealth of American households: Evidence from the Survey of Consumer Finances. Report to the Consumer Federation of America. Retrieved May 24, 2005, from Consumer Federation of America Web site: http://www.consumerfed.org/evidence.pdf . 


\section{Jessie X. Fan and Cathleen D. Zick}

National Funeral Directors Association. (2001). Funeral price information. Retrieved May 24, 2005, from http://www.funeral.com/funeral/index.jsp?dirID=33520.

Paulin, G. D. (1995). A comparison of consumer expenditures by housing tenure. Journal of Consumer Affairs, 29(1), 164-198.

Paulin, G. D. (2000). Expenditure patterns of older Americans, 1984-97. Monthly Labor Review, 123(5), 3-28.

Paulin, G. D., \& Duly, A. L. (2002). Planning ahead: Consumer expenditure patterns in retirement. Monthly Labor Review, 125(7), 38-58.

Paulin, G. D., \& Lee, Y. G. (2002). Expenditures of single parents: How does gender figure In?. Monthly Labor Review, 125(7), 16-37.

Prais, S. J., \& Houthakker, H. S. (1971). The analysis of family budgets. 2nd edition, Cambridge: Cambridge University Press.

Rubin, R. M., \& Nieswiadomy, M. L. (1997). Expenditures of older Americans. Westport, CT: Praeger.

Tan, L. (2000). Spending patterns of public-assisted families. Monthly Labor Review, $123(5), 29-35$.

U.S. Bureau of Labor Statistics, Department of Labor (1980-2001). Consumer Expenditure Survey, Ann Arbor, MI: Inter-University Consortium for Political and Social Research.

Weir, D. R., \& Willis, R. J. (2000). Prospects for widow poverty. In O. S. Mitchell, P. B. Hammond, \& A. M. Rappaport (Ed.), Forecasting retirement needs and retirement wealth (pp. 208-234). Philadelphia: University of Pennsylvania Press.

Zick, C. D., Fan, J. X., \& Chang, K.-L. (2004). Impending widowhood and spending on health care. Social Science Research Journal, 33(3), 538-555.

Zick, C. D., \& Holden, K. C. (2000). An assessment of the wealth holdings of recent widows. Journals of Gerontology Social Sciences, 55, S90-S97.

Zick, C. D., \& Smith, K. R. (1991). Patterns of economic change surrounding the death of a spouse. Journal of Gerontology: Social Sciences, 46, S310-S320. 